\title{
THE DEVELOPMENT OF BIOECONOMICS IN UKRAINE AS AN ELEMENT OF TRANSFORMATION GOVERNMENT STRATEGY OF SUSTAINABLE DEVELOPMENT
}

\author{
${ }^{1}$ Tetiana Gorokhova, ${ }^{2}$ Leila Mamatova, ${ }^{3}$ Hanna Muterko \\ ${ }^{1}$ Associate Professor, Priazovskyi State Technical University, 7 Universitetska str., Mariupol, Ukraine, \\ Email address tanyagorokhova88@gmail.com \\ ${ }^{2}$ Ph.D., Priazovskyi State Technical University, 7 Universitetska str., Mariupol, Ukraine \\ ${ }^{3}$ Ph.D., Priazovskyi State Technical University, 7 Universitetska str., Mariupol, Ukraine
}

Received 0504 2020; Accepted 01092020

\begin{abstract}
The article considers the possibilities and prospects of bioenergy development in the world and in Ukraine as an alternative energy source and an element of sustainable development. The main objectives of the article are to analyze the dynamics of bioenergy implementation in Ukraine, to consider the current state of bioeconomy development in Ukraine, and to propose an algorithm for the transformation of economic systems in Ukraine into bioeconomic systems. The research methodology based on analyzing statistical data of world countries and Ukraine, to compare the development of the bioeconomy in the world with trends in Ukraine, and also based on methods of analysis and synthesis to develop an algorithm for the development of bioenergy in Ukraine. The authors studied the dynamics of the use of renewable energy resources in the world. The article considers the state and prospects of the development of renewable energy in Ukraine. Authors determined that the development of the bioeconomy would prolong the life of natural resources, reduce the environmental load, and provide an opportunity to improve the living conditions of mankind, to obtain the additional value of products from the use of waste. The results of the research will be useful and interested in scientists, bioenergy specialists, and all stakeholders.
\end{abstract} development.

Keywords: bioeconomics, biotechnology, renewable energy, responsible consumption, sustainable

JEL Codes: F20, L94, M11, O13, Q29, Q49.

\section{Introduction}

The growing concerns about climate change, environmental pollution, depletion of fossil resources, population growth in the world have led to the increasing attention of scientists to technologies based on renewable resources and leveling unwanted externalities such as harmful effects on the environment.

Significant developments in life sciences (genome research, DNA, molecular and cell biology, virology, etc.) have led to increased interest in expanding the use of modern biology-based technologies that use organic matter to produce products for human consumption and for producing processes of other types. Thus, the concept of bioeconomics is to some extent interdisciplinary, which covers new phenomena and processes associated with the use of bio-based technologies in the production, exchange, distribution, and consumption of needs goods/benefits for humans.

The development of the bioeconomy solves serious problems such as increasing food production, energy production from renewable sources, and the associated reduction in dependence on non-renewable fossil fuels, creating additional jobs and increasing employment, reducing the burden on the environment by reducing harmful emissions and recovery of the population, etc.

Copyright (C) 2020. Published by Vytautas Magnus University. This is an open access article distributed under the terms of the Creative Commons Attribution Non-Commercial 4.0 (CC BY-NC 4.0) license, which permits unrestricted use, distribution, and reproduction in any medium provided the original author and source are credited. The material cannot be used for commercial purposes. 
At the same time, there are a number of arguments that significantly reduce the enthusiasm of supporters of the bioeconomy, namely the intensification of competition for raw materials needed for both food production and fuel production, which can lead to significant increases in food prices; the need for significant "start-up" costs for the transition to bio-based technologies; lack of the necessary infrastructure and logistical problems, which lead to high costs for transportation, storage of raw materials, etc., and thus increase the cost of the original "bioproduct", making it thus uncompetitive compared to traditional counterparts. Currently, human development faces a number of global challenges, namely: rapid population growth, consumer crisis, economic backwardness, environmental degradation, inefficient use of energy and raw materials, which form public uncertainty about its permanent future. Such fears of society generate resistance due to the rise of scientific and technological progress, which, given the current trends in the European space, gives impetus to the activation of the bioeconomy in the agricultural sector of Ukraine. The priority areas of the bioeconomy are the creation of preconditions for the economical use of natural resources, minimization of environmental risks, the spread of organic farming, and the use of energy-saving technologies. Under such conditions, the bioeconomy is able to solve the problems of efficient use of the biological system with the least harm to the environment and in general, to harmonize the socio-economic development of society.

The scientific problematic of this article is the issue of insufficient attention of domestic science and the country's economy to the transformation processes of economic systems into the bioeconomy based on using main bioeconomy resources taking into account the perspective of Ukraine's sustainable development.

The hypothesis of the article is based on a complex view on the formation of the bioeconomic system of Ukraine in the context of The Concept of Sustainable Development and the Strategy for Sustainable Development of Ukraine 2030.

The aim of this research is to generalize the theoretical definitions of the bioeconomy, analyze the current state of the bioeconomy in Ukraine and outline further prospects for its development.

The research objective is to identify trends in the formation of Ukraine's bioeconomy in the context of bioeconomy development in the EU.

The research subject is the possibility of using the available resources of Ukraine to achieve sustainable development of the country as a whole.

Research methods: historical, dialectical, method of cognition, as well as a systematic approach and comparative analysis, statistical methods.

Elements of scientific novelty. The authors determined that bioeconomics as a science, in contrast to existing ones, studies the management of resources and technologies on a circular basis.

Practical significance. The authors prove that the bioeconomy is a new direction of economic development, which reuses and recycles secondary raw materials, including waste, creates conditions for multiple, cyclical use of resources, providing increase and improving the socio-economic development of the country. The use of biotechnology creates the basis for the formation of the bioeconomy as a system that creates biological resources for the production of high-tech products.

\section{Literature analysis}

Problems of origin and development of the economy, based on the application of biological technologies, are studied in the works of such scientists as, Alan Bennett, Gerald A. Carlson, David Zilberman, Colin W. Clark, Juan Enriquez-Cabot, Gregory Graff, Kvasha S., Klimenko A., Novikov V., and others.

Theoretical, methodological and practical aspects of economic development on a bioeconomic basis are devoted to the scientific works of scientists: Beekman V., Brown L., Cotianu 
R., DaSilva E., Georgescu-Roegen N., Gore A., Muller M., Voineagu V., Dulska I., Klimenko A., Litvak O., Makarchuk O., Talaviri M. Significant results have been achieved in the study of environmental and bioeconomic aspects of economic development, while the problem of an integrated approach to environmental security and social development through the prism of the bioeconomy remains insufficiently resolved.

\section{Methodology}

The research methodology is based on a set of theories of management of sustainable development of economic systems and bioeconomy in the context of globalization, convergence and transnationalization of a market economy. The empirical basis of the study is the work of domestic and foreign scientists on the formation and development of sustainable economic development, bioeconomic processes, statistical reporting, public reporting of world countries in the field of bioeconomics, data from international news agencies, Ukrainian legislation on renewable energy, financial reporting and plans of socio-economic development of countries and regions, materials of scientific conferences, results of analytical calculations.

General scientific and special research methods were used to solve the tasks set in the work: historical analysis to study the features and prerequisites for the formation of a sustainable economic strategy; systematization for generalization of the conceptual and categorical apparatus on the theory of formation and content of the concept of bioeconomics and substantiation of prerequisites for improving the concept of formation and development of bioenergy strategy; analysis and synthesis in the study of transformation processes that took place in the world and Ukraine and determine the main characteristics of the degree of use of bioeconomic potential; comparative analysis in the development of the algorithm for the transition of economic systems to bioeconomic systems to achieve a strategy of sustainable economic development.

\section{Results and discussion}

The economy of modern developed countries is characterized by the predominance of hightech industries and services in its structure. Nano- and biotechnologies have particular importance in this context, which have already become a kind of business card not only in Europe but also in many developed countries from around the world. Effective global collaboration is crucial to achieving the UN Sustainable Development Goals (SDGs). It requires an understanding of the needs of individual countries and their expectations related to bioeconomy. Global trade in biobased products has been booming over the last decade. Global biofuel production increased by 10 billion liters in 2018 to reach a record of 154 billion liters. Double the growth of 2017, this 7\% year-on-year increase was the highest in five years. The output is forecast to increase $25 \%$ to 2024 , an upwards revision from 2018 owing to better market prospects in Brazil, the United States, and especially China (Fig. 1).

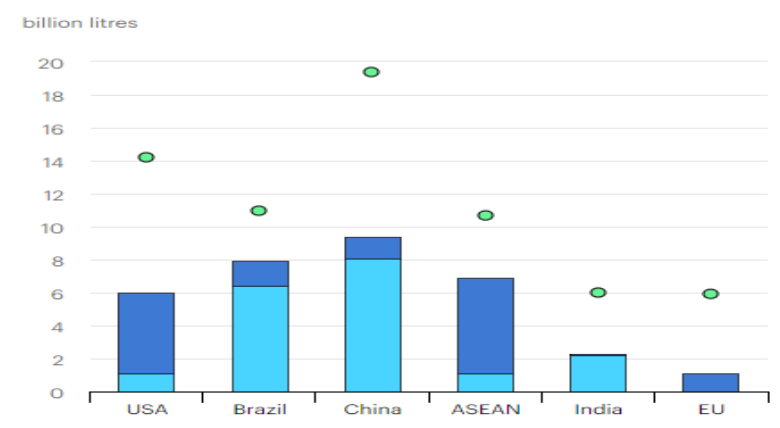

Fig. 1. Biofuel production growth in key markets, 2019-2024 (IEA, 2019) 
Ukraine was one of the first European countries to ratify the Paris Agreement on July 14, 2016. One of the arguments was the issue of significant climate change in Ukraine, which increases the risks to human health and life, natural ecosystems, and economic sectors, as well as ensuring national, ecological, economic, and energy security of Ukraine. The main negative consequences of climate change in Ukraine, which Ukrainian scientists talk about, are increased risks to human health associated with almost all manifestations of hydrometeorological phenomena; significant reduction in yields of major crops; exacerbation of problems with water supply not only in the southern and south-eastern regions; increasing land degradation and desertification; reduction of productivity, viability, and sustainability of forests; accelerating the degradation of ecosystems; the occurrence of accidents and unstable functioning of electric networks and centralized heating systems, other infrastructure facilities and much more.

Thus, the authors propose an algorithm for the transformation of economic systems to an ecocentrism approach (Fig. 2).

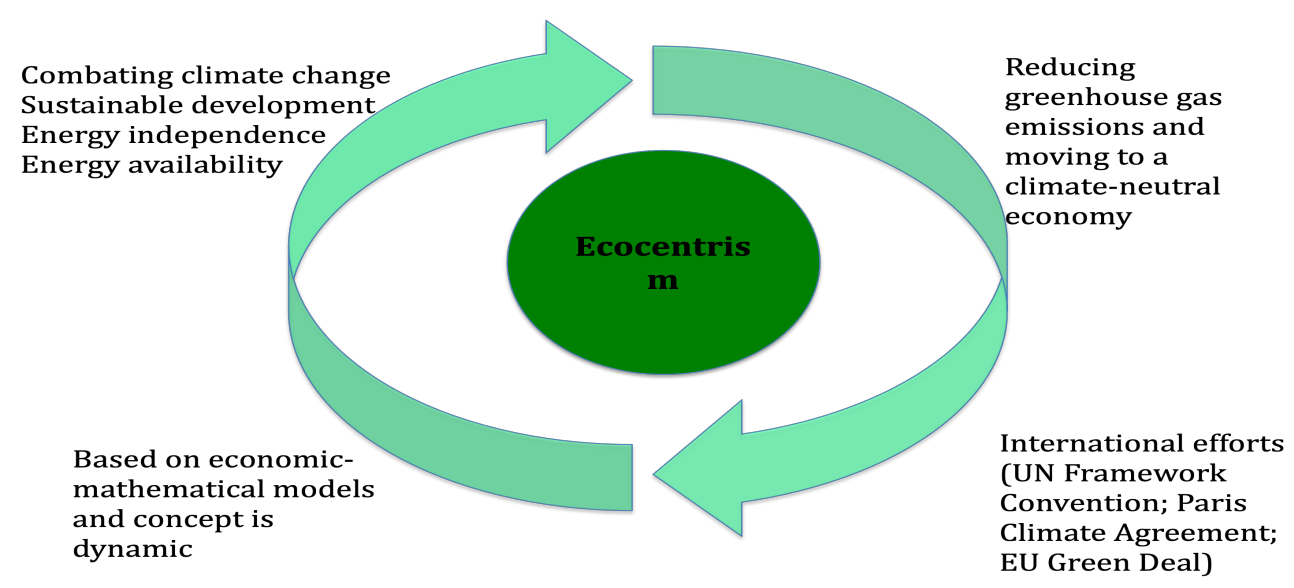

Fig. 2. Changing the paradigm of energy policy in Ukraine

Sources: compiled by the authors

Energy efficiency and renewable energy sources (RES) are becoming key areas of Ukraine's energy transition. Significant progress in improving energy efficiency will significantly reduce the need to produce additional energy resources needed for projected GDP growth and improving the well-being of citizens. At the same time, the structure of the required energy resources will undergo significant changes, primarily due to advanced electrification of the economy (transport, industry, buildings), which will require a significant increase in the share of RES in electricity generation and a corresponding reduction in fossil fuels. In turn, the "green" energy transition will achieve the following main goals:

1. Ukraine is an energy-independent and security-resistant country.

2. Energy production and consumption are sustainable in Ukraine.

3. Ukraine is a country with a climate-neutral economy until 2070.

Energy efficiency and economical use of resources is one of the main directions of Ukraine's "green" energy transition and will remain a constant priority of the Government. To implement this priority, it is necessary to implement policies and measures aimed at improving the efficiency of energy resources and energy conservation while improving the quality of energy services and energy supply. The focus should be on the residential sector, which has the greatest potential for energy efficiency (Fig. 3).

Ukraine has significant natural potential for a "green" transition in all sectors of the economy. Given the capabilities and availability of modern renewable energy technologies, as 
well as their rapid development, Ukraine is quite capable and economically feasible by 2050 to reach $70 \%$ of the share of RES in electricity generation.

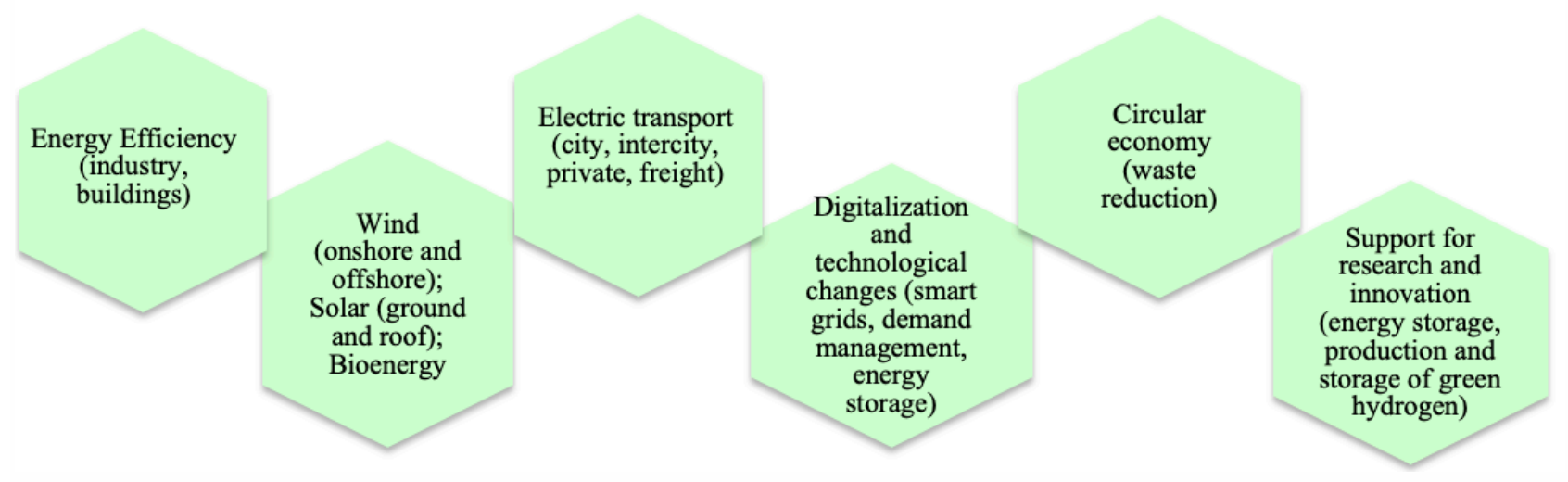

Fig. 3. Main directions of the "green" energy transition

Sources: compiled by the authors

Moreover, a significant part (up to $15 \%$ ) should be the production of electricity from rooftop solar power plants in households and businesses.

Energy efficiency and responsible consumption of resources is one of the main directions of Ukraine's "green" energy transition and will remain a constant priority of the Government. To implement this priority, it is necessary to implement policies and measures aimed at improving the efficiency of energy resources and energy conservation while improving the quality of energy services and energy supply. The focus should be on the residential sector, which has the greatest potential for energy efficiency.

$R E S$, combined with energy efficiency improvements, form the most powerful tool in decarbonizing national and global economies.

Digitalization is a modern trend of transformation of economic relations and will be accompanied by a significant reduction in the involvement of natural and technical resources, the volume of their physical movements. Digitalization process will speed up economic and administrative processes, provide services remotely, facilitate governance, optimize the movement of people, and the use of transport. These effects will contribute to the development of resource- and energy-efficient, climate-neutral economy.

Agriculture has a small share in the structure of final energy consumption, however, this sector has sufficient potential to increase energy efficiency and the transition to renewable energy sources, and help other sectors of the economy.

To realize this potential it is necessary:

- increase energy and resource efficiency of agricultural and food production;

- reduce the consumption of carbon-intensive energy resources to zero and maximize the use of RES so that this sector of the economy switches to full self-sufficiency in energy resources;

- increase sustainable production of biomass, biofuels and other RES to support the implementation of the "green" transition in other sectors of the economy.

- forestry plays a key role in non-technological GHG uptake, so the state as the main owner of forest lands has the opportunity to expand the potential of net GHG uptake and retention through: increasing the area of land covered with forest vegetation, creating new forests; sustainable forest management, taking into account climate change in accordance with the concept of Climate Smart Forestry, increasing the level of productivity and sustainability of forests; reduction of deforestation, timely restoration of forests, rational placement of forests and plantations, stimulation of measures for landscaping of settlements. 
According to UNDP/GEF Project Manager "Development and Commercialization of Bioenergy Technologies in the Municipal Sector in Ukraine" Yevhen Groza (2017): "Biomass is one of the most promising renewable energy sources. Despite its limited use in Ukraine, in the structure of energy production from renewable sources in 2017, biofuels and waste accounted for the largest share $-80 \%$. The growth rate of the bioenergy sector in Ukraine is constantly growing: $43 \%$ per year in terms of "biofuel and waste production" and 33\% - in terms of total supply of primary energy from biofuels and waste". In total, bioenergy replaced 3.8 billion $\mathrm{m}^{3}$ of natural gas in 2017 .

Ukraine's energy sector depends on imports of fossil fuels (natural gas, oil, coal), which poses a significant risk to the country's energy security. Thus, in 2017 , the cost of purchasing imported energy (petroleum products, natural gas, and coal) in Ukraine amounted to more than 11 billion US dollars. A significant reduction in these costs can be achieved through the development of renewable energy sources, its own natural gas production, as well as increasing the energy efficiency of the economy (Fig. 4).

Ukraine already implements best European practices for using biomass potential for municipal heat and hot water supply.

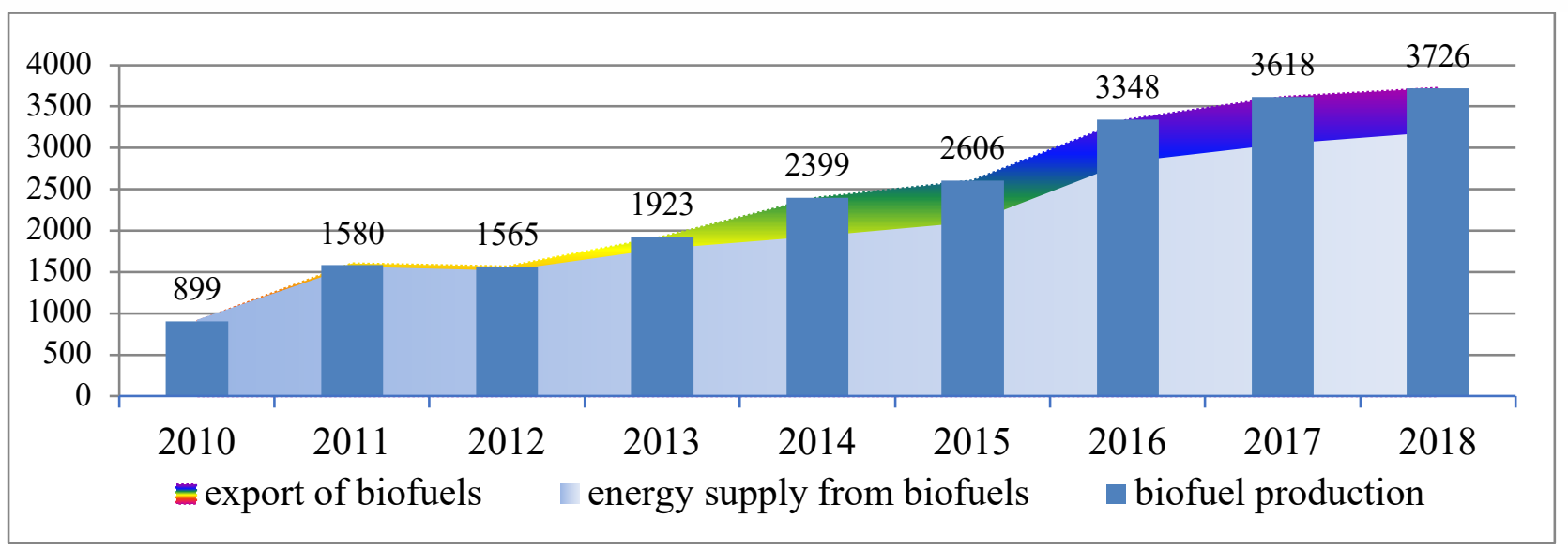

Fig. 4. Growing level of bioenergy in Ukraine (Bioenergy Association of Ukraine, 2019)

There are many existing bioenergy projects in Ukraine, for instance: boiler houses with solid fuel boilers in Zhytomyr and Kyiv regions, a plantation of energy crops of the Institute of Bioenergy Crops and Sugar Beets of the National Academy of Agrarian Sciences in the Kyiv region and an energy poplar plantation in the Zhytomyr region, an enterprise for the production of boilers and pellets from straw in the Cherkasy region, as well as equipment for the production of straw briquettes in the Kyiv region. The knowledge and experience gained will help municipalities to ensure the successful commissioning of heat supply facilities that have received technical assistance from UNDP. Ukraine ranks 13th among 15 EU countries that use green as a means to stimulate electricity production from biomass and biogas. We have one of the lowest tariffs for the bioenergy sector among EU countries.

Ukraine ranks 13th among the 15 EU countries that use the "green" tariff to stimulate electricity production from biomass and biogas (Fig. 5). According to the National Renewable Energy Action Plan approved by the Government and agreed with the Energy Community, the installation of solar capacity in the amount of 2,300 MW is envisaged by the end of 2020 . However, by the end of the first quarter of 2020, the country had already installed 5,576.3 MW of solar capacity. For comparison, the total capacity of biomass and biogas power plants reached 98.6 MW, which is almost seven times less than planned. 
The market for balancing and ancillary services is not working due to the lack of sufficient maneuverability in the country. According to Ukrenergo's (2019) calculations, for the effective integration of RES into the unified energy system of Ukraine and its safe operation, the following maneuvering and energy storage capacities are required: for $2021-1.6 \mathrm{GW}$, for $2025-1.8 \mathrm{GW}$, for $2030-2 \mathrm{GW}$. It is critical to start their construction now and launch at least $300 \mathrm{MW}$ of new shunting capacity or storage by the end of 2020 (table 1).

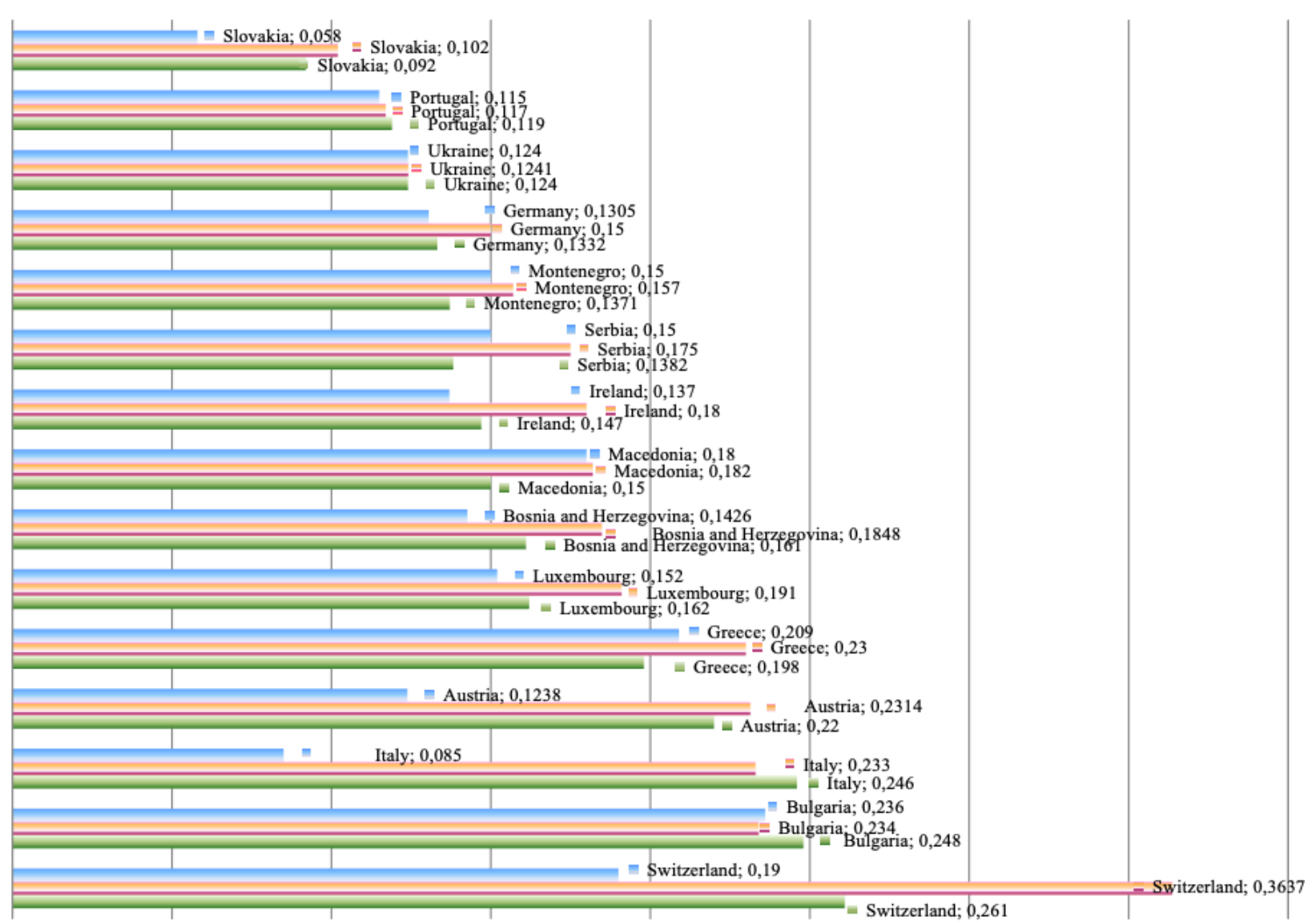

= Green tariff for electricity from biogas $2020 \quad$ = Green tariff for electricity from biogas $2019 \quad$ « Green tariff for electricity from biomass 2019

Fig. 5. "Green" tariffs for electricity from biomass among European countries in 2019, 2020 (Bioenergy Association of Ukraine, 2020)

Table 1. Installed capacity, generated electricity, distribution of green tariff payments by types of renewable generation in Ukraine in 2019

\begin{tabular}{|c|c|c|c|c|c|c|}
\hline & $\begin{array}{l}\text { Wind } \\
\text { Farms } \\
\end{array}$ & Biomass & Biogas & $\begin{array}{c}\text { Solar power } \\
\text { plants }\end{array}$ & $\begin{array}{l}\text { Micro hydroelectric } \\
\text { power plants }\end{array}$ & Total \\
\hline \multicolumn{7}{|l|}{ Installed capacity } \\
\hline at the beginning of $2019, \mathrm{MW}$ & 532.9 & 52.8 & 45.8 & 1367.2 & 110.1 & 2109.0 \\
\hline at the end of $2019, \mathrm{MW}$ & 1169.9 & 83,9 & 86.1 & 4924,6 & 113.9 & 6378.6 \\
\hline Distribution of installed power, $\%$ & $18 \%$ & $1 \%$ & $1 \%$ & $77 \%$ & $2 \%$ & $100 \%$ \\
\hline $\begin{array}{l}\text { Generation of electricity, } \\
\text { million kWH per year }\end{array}$ & 2021.6 & 162.3 & 247.4 & 2932.3 & 241.5 & 5605.4 \\
\hline Distribution of generated electricity, $\%$ & $36 \%$ & $3 \%$ & $4 \%$ & $52 \%$ & $4 \%$ & $100 \%$ \\
\hline $\begin{array}{c}\text { Basic "green" tariff IV quarter } 2019 . \\
\text { cent } / \mathrm{kW} * \text { year }\end{array}$ & 9.4 & 11 & 11 & 14 & 12 & \\
\hline $\begin{array}{c}\text { Distribution of payments at the "green" } \\
\text { tariff, } \%\end{array}$ & $28 \%$ & $3 \%$ & $4 \%$ & $61 \%$ & $4 \%$ & $100 \%$ \\
\hline
\end{tabular}


A comparison of the structure of electricity generation with RES in Ukraine and the world shows an atypically large share of solar electricity generation in Ukraine. Thus, in the world and in some countries the share of "sun" is $18-24 \%$ of the production of renewable electricity (excluding hydropower), and in Ukraine - 54\%. 61\% of costs are paid for the generated solar electricity at the "green" tariff.

Table 2. Renewable electricity production structure (excluding hydropower) in 2019*

\begin{tabular}{|l|c|c|c|c|c|c|}
\hline \multirow{2}{*}{} & \multicolumn{2}{|c|}{ World, 2019 } & \multicolumn{2}{c|}{ EU, 2019 } & \multicolumn{2}{c|}{ Ukraine, 2019} \\
\cline { 2 - 7 } & $\begin{array}{c}\text { \% from } \\
\text { total } \\
\text { production }\end{array}$ & $\begin{array}{c}\text { Structure, } \\
\%\end{array}$ & $\begin{array}{c}\text { \% from total } \\
\text { production }\end{array}$ & $\begin{array}{c}\text { Structure, } \\
\%\end{array}$ & $\begin{array}{c}\text { \% from total } \\
\text { production }\end{array}$ & $\begin{array}{c}\text { Structure, } \\
\%\end{array}$ \\
\hline Solar energy & 2.2 & 24 & 4.2 & 18 & 1.9 & 54 \\
\hline Wind energy & 4.8 & 53 & 13.4 & 56 & 1.3 & 37 \\
\hline Biomass & 2.0 & 22 & 6.2 & 26 & 0.3 & 9 \\
\hline Total & 9.0 & 100 & 20.1 & 100 & 3.5 & 100 \\
\hline
\end{tabular}

* - the analysis was performed without hydropower to avoid impact on the results of large hydropower.

The main mechanism for supporting vulnerable consumers should be targeted social support, based on the income of individual households. Any benefits and subsidies should be monetized and accrued on the basis of the total cost of energy (including taxes and fees). The consequence of the social assistance reform should be a reduction in the share of consumers eligible for such support to the average level in the EU countries (not more than 10\%). In parallel, other consumer protection mechanisms need to be put in place - the practical application of individual bankruptcy and debt restructuring, energy saving advice, soft loans and / or subsidies to replace inefficient energy appliances. One of the key solutions for vulnerable consumers should be greater availability of government energy efficiency programs. The gradual penetration of "smart" energy appliances and the "Internet of Things" will create opportunities for consumers - first industrial, but later household - to earn on the market. This includes both demand management and the use of household systems for energy storage, participation in balancing (Fig. 6).

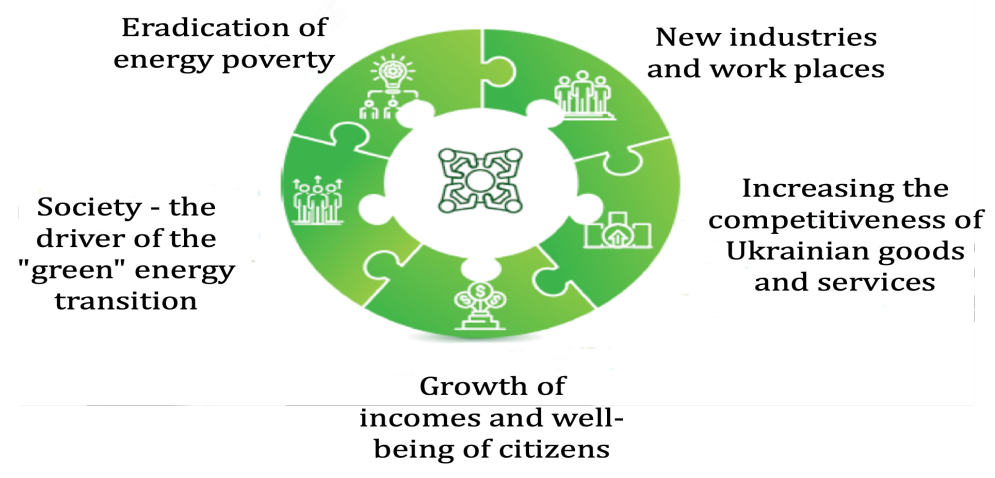

Fig. 6. Reasons to develop bioenergy in Ukraine (social aspects)

Sources: compiled by the authors

About $50 \%$ of these biofuels will be used for thermal energy production and will directly replace natural gas (equivalent to replacing 13.7 billion $\mathrm{m}^{3}$ / year of natural gas). The other part will replace coal and nuclear generation for electricity generation, as well as petroleum products in transport. In the period 2020-2050 in Ukraine, the use of wood biomass will remain at the same 
level, but the share of use of straw, stems, sunflower husks, agricultural residues, energy crops, liquid biofuels, solid waste for energy production will increase. This forecast is based on calculations that show that the potential of wood biomass and sunflower husks in Ukraine in 2020 has already been used by more than $90 \%$ (Fig.6).

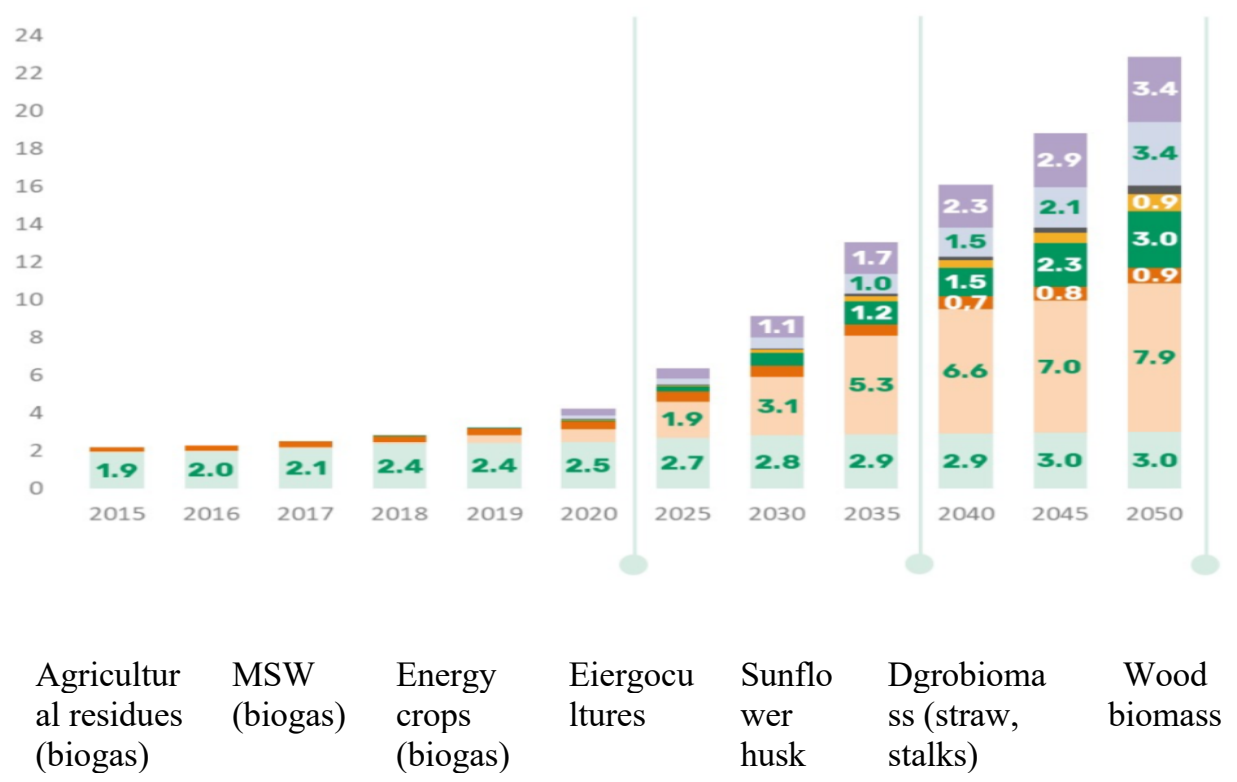

Fig. 6. UABIO forecast for the development of bioenergy in Ukraine in 2020-2050 (Bioenergy Association of Ukraine, 2020)

\section{Conclusion}

New scientific discoveries in the field of biotechnology and the need to reduce environmental pressures are leading to the emergence of a bioeconomy. The emergence of the bioeconomy is an ongoing evolutionary process of transition from the system of consumption and processing of non-renewable resources to the system of using renewable. However, the development of the bioeconomy requires continuous investment in research and innovation, as well as the creation of appropriate financial mechanisms that ensure private sector investment. One of the most important tasks is the creation and development of a regulatory framework that regulates externalities from new biotechnology products that are undesirable to society and, at the same time, does not stop the development of such an innovative and promising sector as the bioeconomy. The gradual development of the world economy requires a significant increase in energy production. At the same time, stocks of traditional natural fuels, such as natural gas, oil, and coal, are gradually declining. In addition, increasing the use of natural non-renewable resources leads to an increase in carbon dioxide emissions into the environment. One of the ways to reduce the pressure on the environment and reduce the impact of human activities on climate change is the development of the bioeconomy, in particular the bioenergy, which uses renewable resources to produce electricity, heat and fuel. For more efficient development of bioenergy, such instruments of state regulation as taxes (in particular, taxes on $\mathrm{CO} 2$ emissions) and tariffs (in particular - ,green“ tariffs for bioenergy production) should be used. The use of these instruments of state regulation of bioeconomy development can serve as an incentive to reduce emissions and at the same time provide compensation for environmental and economic damage. Bioeconomics has a number of advantages, including: diversification of the agricultural economy and its sustainable growth; development of rural 
regions and territories; improving the social situation in cities; improving public health, ecology and quality of life; reduction of production costs and product quality control; the emergence of new products; reduction of dependence on fossil energy resources; reduction of environmental pollution; creation of new materials and fuels from biological raw materials; use of reusable and processed products. The development of the bioeconomy will prolong the life of natural resources, reduce the environmental burden, provide an opportunity to improve the living conditions of mankind, get additional value from waste products and more.

\section{References}

Bioenergy Association of Ukraine (2020). Non-profit community association that brings together business and experts to bioenergy development in Ukraine. - https://uabio.org/en/ [2020 06 25].

Enriquez-Cabot,(J. 1998). Genomics and the World's Economy // Science. No.281: 925-926.

Viaggi Davide, Mantino Francesco, Mazzocchi Mario, Moro Daniele, Stefani Gianluca (2012). From Agricultural to Bio-based Economics? Context, State of the Art and Challenges // Bio-based and Applied Economics Italian Association of Agricultural and Applied Economics (AIEAA), vol.1(1): 3-11.

IEA - International Energy Agency. - https://www.iea.org/ [2020 06 25].

Dulska, I.V. (2012). Will Ukraine drive by high-speed train of STP? (technological development manifesto of the country) // Bulletin of the International Nobel Economic Forum. No.1 (5), Vol. 1: 80-92.

Litvak, O.A. (2016). Development of agrarian sector economy is on bioeconomic principles. Extended abstract of candidate's thesis. Mykolaiv. $20 \mathrm{p}$.

Makarchuk, O.H., Savchuk, V.K. (2011). Biopower potential of agricultural production: economic measuring, prognosis of the use. - Kyiv: Agrar Media Grup. 177 p.

Talavyria, M.P. (2015). Development of bioeconomics and environmental management in the conditions of globalization. Monograph. Scientific Bulletin of Uzhhorod University. Ser. Economy. 2015. No. 1 (45). Vol. 2: 225-229.

Biomass-renewable energy from plants and animals. (n.d.) // U.S. Energy Information Administration. - https://www.eia.gov/energyexplained/?page=biomass_home [2020 05 23].

Bogdan, M., Buianu Lapadat, Vergina, Cotianu, R. Florescu, Georgiana (2000). Economics. Bucharest. Romania: Universitas Publishing House.

Brown, L.R. (2001). Eco-economy - building an economy for Earth. - Bucharest. Romania: Technical Publishing House.

DaSilva, E.J. The colours of biotechnology: Science, development and humankind // Electronic Journal of Biotechnology. $\quad-\quad$ http://www.ejbiotechnology.info/ index.php/ejbiotechnology/article/view/1114/1496 [2020 05 24].

Georgescu-Roegen, N. (1971). The entropy law and the economic process. - USA. Cambridge: Harvard University Press.

Gore, A. (1994). Earth in balance. Ecology and the human spirit. - Bucharest: Technical Publishing.

Jordan, N., Boody, G., Broussard, W., Glover, J.D., Keeney, D., McCown, B.H. (2007). Sustainable development of the agricultural bio-economy. - http:www.sciencemag.org [2020 06 13].

Overbeek, G., de Bakker, E., Beekman, V., Davies, S., Kresiewa, Z., Delbrück, S. (2016). Review of bioeconomy strategies at regional and national level // BioSTEP Project, Report D2.3. - http://biostep.eu/fileadmin/Bio-STEP/Bio_documents/BioSTEP_D2.3_Review_of_strategies.pdf [2020 06 01].

Voineagu, V. (2006). Bio-economic revolution, history of occidental economy reconciliation with evolutionary biology, Centenary of birth of Nicholas Georgescu-Roegen (1906 - 2006). - Bucharest, Romania. National Institute of Statistics. - http://www.insse.ro [2020 07 02]. 